\title{
Teacher Management In Integrated Islamic School
}

\author{
Sukirdi 1,a , Bedjo Sujanto 1,b, Ivan Hanafi 1,c \\ ${ }^{1}$ Department of Educational Management, Postgraduate of State University of Jakarta, Jakarta, Indonesia \\ a sukirdi_mp16s3@mahasiswa.unj.ac.id; b bedjo1951@unj.ac.id; c ivan.hanafi@unj.ac.id \\ *Corresponding Author
}

How to Cite : Sukirdi, S., Sujanto, B., Hanafi, I. (2019). Teacher Management In Integrated Islamic School. International Journal for Educational and Vocational Studies, 1 (8), 823-830. DOI: https://doi.org/10.29103/ijevs.v1i8.2268

\section{ARTICLE HISTORY}

Received: 13 September 2019

Revised: 27 October 2019

Accepted: 20 November 2019

\section{KEYWORDS}

Teacher;

Training and Development,

Selection;

\section{ABSTRACT}

This aims of this study is to find, to describe, and to inform about the management of teachers at SDIT Iqra 1 Bengkulu. This research used a qualitative approach by using a case study method. The data was collected by observation, interview, and documentation techniques. The data analysis used interactive analysis start from: data collection, data presentation, data reduction, and collection conclusion. The results of this study contain patterns of teacher training and development at SDIT Iqra 1 Bengkulu which are different from commonly schools. The differences are in:The difference are selection of applicants written and unwritten, and interviews In addition, the differences in training and development include two the main aspects are aspects of training and development of education and religious knowledge which is carried out continuously for all teachers ranging from school principals to ordinary teachers with the pattern of forming training and development groups.

\section{INTRODUCTION}

School is an educational institution that is composed of various elements in it such as the principal, vice principals, teachers, administrators education, and learners, all of them require professional management so that school rotates in its orbit as well towards the goals set. Teacher management is the main priority, it is an important compass that determines the direction of good and bad schools, one indication of good teacher management is that teachers get a clear and balanced portion of their duties and responsibilities based on their respective potentials. The existence of teachers becomes very important as educators must be recognized by all stakeholders. Teacher, it is a human resource owned by an organization that is used to mobilize or manage other resources so that it must really be used effectively in an efficient fund according to the real needs of the organization (Yullyanti, 2009).

In the Republic of Indonesia Law Number 20 Year 2003 concerning the National Education System Article 29 Paragraph 2 "educators are professionals who are tasked with planning and implementing the learning process, assessing learning outcomes, conducting guidance and training, and conducting research and community service, especially for the educator at the higher education". In addition, the teacher is also required to carry out the obligations imposed on him. In article 20 of Law RI Number 14 of 2005 concerning Teachers and Lecturers stated that teachers in carrying out their duties have several obligations, namely: (1) Planning learning, implementing quality learning processes, and assessing and evaluating learning outcomes. (2) Improving and developing academic qualifications and competencies in a sustainable manner in line with the development of science, technology, and art. (3) Acting objectively and not discriminatory on the basis of consideration of gender, religion, ethnicity, race, and certain physical conditions, or family background, and socio-economic status of students in learning. (4) Upholding the statutory regulations, and the teacher's code of ethics, religious and ethical values, and (5) maintaining and fostering national unity and integrity.

Tilaar (2012:167) reveals that teachers are the foremost soldiers in opening up the horizons of students entering the world of science in today's global era. That is why professional teachers are required to have special competencies, namely: pedagogical competence, personal competence, social competence, and professional competence. Problems of education during this time can 
not be separated from the existing problems in teachers, Competency-competencies that must be aligned properly united in the soul of a teacher, let alone faced disruption and the industrial revolution era. This competency will be a determinant of the merits and performances (understanding of teacher performance according to Kartomo (2016).

SDIT Iqra 1 Bengkulu is one of the private elementary schools that has local, national and international academic and non academic achievements, students and teachers. SDIT Iqra 1 achievements in Bengkulu City include: the third place in the national quality culture competition, every year the teacher are included in the line of outstanding teachers, as well as the school principal, as a national independent Adiwiyata, becoming the winner of a healthy school competition, becoming local and national pilot school this is proven by the many teachers and principals in the city of Bengkulu, teachers and school principals in districts in Bengkulu, and neighboring provinces, even from Java islands making SDIT Iqra 1 Bengkulu City as a comparative study reference. They have qualified teachers at the start since recruitment and selection to training, and development sustainable are performed by the school. As part of labor management, recruitment is related to other employment functions.

\section{METHODS}

The purpose of this research is to explore and to inform about the selection, training and development of teachers in SDIT Iqra 1 Bengkulu. The time of the study will be from January to March 2019. The approach used in this study is a qualitative approach. Qualitative approach is used as the expression Moleong (2007:275), namely: "qualitative research is rooted in natural background as a whole, relying on people as a means research, utilizing qualitative methods, and inductive data analysis. Qualitative research is used to examine the natural conditions of objects, in this study the researcher acts as a key instrument, the data collection techniques are carried out by triangulation (a combination of observations, interviews, documentation), the data obtained to be qualitative, data analysis is inductive/qualitative, and the qualitative research results are to understand meaning, understand uniqueness, construct phenomena, and find hypotheses (Sugiyono, 2017:9-10).

This qualitative study using the case study method that refers to research that has elements of how and why, researchers have little opportunity to control the events to be investigated, and when the focus of research lies in contemporary phenomena (present) in the context of real life (Yin, 2002:1). Researchers explore and exploit limited systems (case studies) in detail through in-depth data collection involving many sources of information, such as researchers conducting observations, interviews, and documentation.
The data needed in this study is related to teacher selection, training and teacher development at SDIT Iqra 1 Bengkulu. The data was obtained through data sources directly namely the subject who became the informant. Primary data, in the form of verbal words or language from informants directly related to the administration of education in SDIT Iqra 1 Bengkulu. While secondary data in the form of data that is not directly obtained from the informant, namely data derived from various written documents that are closely correlated to the management of SDIT Iqra 1 Bengkulu.

Researchers obtained research data; first, observations, namely: teacher activities at school, teacher daily activities, weekly agendas, monthly principals, and various activities at school (training, workshops, ceremonies, religious activities, scouting, extracurricular, and etc.), interactions between the principal and the teacher, interactions between the teachers. Second, researchers conducted interviews with six informants consisting of, namely: the principal of SDIT Iqra 1 Bengkulu, the deputy headmaster of curriculum in SDIT Iqra 1 Bengkulu, the deputy headmaster of student affairs at SDIT Iqra 1 Bengkulu, vice-principal of the field of relations with the people of SDIT Iqra 1 of Bengkulu, the deputy head of the school in the field of facilities of SDIT Iqra 1 of Bengkulu, and the deputy head of the field of 'ulumul syar'i SDIT Iqra 1 of Bengkulu. Third, researchers took data in the form of documents, reports or books relating to teacher management in SDIT Iqra 1 Bengkulu.

\section{RESULTS AND DISCUSSION}

To get the teacher who appropiate to their the expectations, SDIT Iqra 1 Bengkulu conducts two stages of administrative selection and test selection. The selection is intended as the phrase Jackson et al. (2009:294) that applicants are assessed to determine their abilities, preferences, interests and personality. Administration selection is intended to select applicants based on the qualification demand and conditions. The test is carried out in two stages namely:

First, a written test which includes namely: a psychological test, professional test, pedagogy test, and the latest developments, after that the test participants are asked to gather the ability to make an integrated learning tool in the form: counting effective weeks, effective days, syllabus, lesson plans, questions and curriculum analysis. Written tests are conducted to ensure that the teacher does not stutter in making learning tools. This is what is commonly faced by teachers in Indonesia in general as Rohman (2016) said, namely: There are still many teachers in educational institutions that teach without learning tools(RPP), unable to integrate SK and KD.

Second, the non-written tests conducted must be followed by the test takers namely: micro teaching test, 
the ability to read the Qur'an based on recitation, the memorization of the letters in the Qur'an, the test of the ability to practice prayer, prayer reading ability test, as well as the ability to memorize prayer. It has been done by SDIT Iqra 1 Bengkulu as an effort to ensure and to explore that prospective teachers can carry out their professional duties as Shabir (2015:221-232) teachers are professional educators with the main task of educating, teaching, guiding, directing, training, assessing, and evaluating students in early childhood education through formal education, basic education and secondary education.

The next non-written test is interviews, in this stage will be dug about a lot of things about candidate teachers including with respect to private and family life, personal habits, attitudes in carrying out the work in a team, understanding prospective teachers of Islamic outlook, the commitment of prospective teachers in maintaining Islamic morals, the commitment of prospective teachers to work in accordance with the applicable system at SDIT Iqra 1 Bengkulu, work experience and expectations when working as a teacher at SDIT Iqra 1 Bengkulu. The candidate of teachers will also be asked to commit not to work in another place, meaning the teacher is ready to work in totality at SDIT Iqra 1 Bengkulu prospective teachers are asked to commit not to take the prospective civil servant test in the contract period of about two years if they take the test civil servants will get the punishment for the repayment of the tuition fees and guidance provided by the foundation for these two years. Well, why do contract teachers if the test as an ASN candidate returns the education and coaching funds because every teacher who has passed the test is accepted as a teacher at SDIT Iqra 1 Bengkulu will be given treatment in the form of training and fostering ongoing intensive development of the concepts of carrying out tasks in integrated Islamic school environment (SIT), training and development related to teaching abilities. It is supported by Widodo (2017:114) which says that employees who get good training and self-development will be more able to survive and be productive in working when a crisis occurs or under normal conditions. Teachers at SDIT Iqra 1 Bengkulu have a high commitment, because one of the causes is programmed and continuous training and development. Another treatment that is carried out by schools is to provide teaching tahsin or reading the Qur'an that is certified by experts. Teachers who pass the test with high commitment will be asked to do a memorendum of understanding $(\mathrm{MoU})$ with the foundation.

One of the researches related to teacher training and development at MAN Yogyakarta in improving its quality so that the vision and mission of the madrasa is achieved. The training and development activities that are broadly outlined are as follows: teacher meetings in subject groups (MGMP), scientific research workshops and teacher learning improvement, implementation of self-development in the Ministry of Religion and Education Ministry MGMP, multi-media education and training, quantum spiritual training learning (SQL), e-learning learning strategy training, advanced studies, madrasa information system development (Muniroh and Muhyadi, 2017)

Meanwhile, in SDIT Iqra 1 Bengkulu City has a unique training and teacher development, it can be seen from the process to become a permanent teacher foundation (GTY) in SDIT Iqra 1 Bengkulu City namely in the training and development of teachers. The goal is as Darodjat (2015: 85) states that: training and development are directed to equip, improve, and develop work competencies in order to improve abilities, productivity and welfare. Starting as an honorary teacher for six months, during this time Iqra 1 SDIT Bengkulu City teachers were given guidance including: training in tahsin or the science of recitation of the Qur'an, memorizing and depositing memorized Qur'an juz juz 30, following religious coaching once a week, assigned teaching as a companion teacher accompanied by a homeroom teacher or senior teacher appointed by the principal, not only that the development of the ability to carry out teaching and learning in the classroom is also observed. Such development as said by Basri and Rusdiana (2002:15) is closely related to efforts to increase the knowledge, abilities, and/or attitudes of organizational members and the provision of career paths supported by organizational flexibility in achieving organizational goals.

The final stage is the evaluation of progress on the ability of teachers to carry out their duties. If it is deemed appropriate and fulfills the requirements, the teacher will continue to be a contract teacher for 1 year. Evaluation is important as a form of assessment that will impress teachers (employees) that their performance is valued by the company (Noe et al., 2010:450). Being a contract teacher is also given coaching the same thing as an honorarium teacher, only a contract teacher if deemed competent can be given a position as homeroom teacher or other assignments. After one year as a contract teacher is evaluated, if the assessment results are good then it will become a foundation permanent teacher candidate for one year, then evaluated if the grades are good then it will become a permanent foundation teacher.

Distinguishing training and development teacher who taught in an integrated environment in Islamic schools (SIT) in addition to having four competency: pedagogical, personality, social, and professional also specifically must have ten competencies commonly referred to muwashofat teacher SIT. Providing training and development continously is useful to increase competitive advantage in a global worldu,"that competitive adventage in the new global economic competition will depend on the close articulation between education and the profit market" (Halsey et al., 1997:161).

This has become a focal point as well as a differentiator for teachers of SDIT Iqra 1 Bengkulu with schools in general. Training and development materials related to the ability to carry out the duties of teachers 
include the following :

Tabel 1. Teacher Training and Development Materials Phase 1

\begin{tabular}{llll}
\hline No. & \multicolumn{1}{c}{ Types of Training and Development } & Sessions \\
\hline & & \multicolumn{1}{c}{ Teacher matriculation: } & 1 session \\
\cline { 2 - 3 } a. & AD/ART Foundation and School & 1 session \\
\hline b. & Teacher Standard Operational Procedures (SOP) & 1 session \\
\hline c. & School profile: Vision, Mission, Objectives, Quality Assurance SDIT Iqra 1 Bengkulu City & 1 session \\
\hline d. & Teacher Compensation System & 1 session \\
\hline e. & Service excellent & 1 session \\
\hline f. & Professional Teacher & 1 session \\
\hline g. & Integrated Learning Concepts in SIT & 1 session \\
\hline h. & Team work & 1 session \\
\hline i. & Micro Teaching & 1 session \\
\hline j. & Integrated Learning Tools Teams & 1 session \\
\hline k. & Pledge of work commitment & & \\
\hline
\end{tabular}

The matriculation material for teacher training and development in the first stage is intended so that teachers have a complete thought building about the institution /school that will be used as a place of work. These materials are mandatory material to be delivered and accepted by all new teachers at SDIT Iqra 1 Begkulu. The material on the foundation's constitution and school's constitution and school draws and confirms the basic rules of the school house. In addition, the teacher is also given material about Standard Operating Procedures (SOP), with this material the teacher performs an act of his profession to start, process, and end work in an orderly, disciplined, and neat manner. Teacher school profile material is required to understand the vision, mission, goals, and quality assurance of the school so that the teacher has a work reference in achieving school goals. Furthermore, teachers are equipped with knowledge of compensation systems, the ability to provide excellent service, understanding concepts as professional teachers, to be able to carry out integrated learning as an Integrated Islamic School (SIT) concept, team work material, micro teaching, making learning tools and pledging work commitments. All, in the end will increase qualified teacher human resources.

Tabel 2. Teacher Training and Development Materials Phase 2

\begin{tabular}{|c|c|c|}
\hline No. & Training and Development Materials & Sessions \\
\hline \multirow[t]{10}{*}{1.} & Educational Material & \\
\hline & a. Curriculum analysis & 2 Sessions \\
\hline & $\begin{array}{l}\text { b. Parallel and curriculum development, Curriculum learning (adapted to each curriculum } \\
\text { development }\end{array}$ & 3 sessions \\
\hline & c. Making integrated learning tools (Syllabus, RPP) & 3 sessions \\
\hline & d. Teacher Success & 1 session \\
\hline & e. Study method & 1 session \\
\hline & f. Student Learning Style & 1 session \\
\hline & g. Teaching Ability & 1 session \\
\hline & h. Age of child development & 2 sessions \\
\hline & i. Learning approaches, methods and strategies & 1 session \\
\hline 2. & Teacher career development & 1 session \\
\hline
\end{tabular}


Through interviews of school principals and deputy principals of SDIT Iqra 1 Bengkulu, the researcher found the meaning of the second stage of teacher training and development material. These materials are intended so that teachers who teach at SDIT Iqra 1 Bengkulu are able to conduct curriculum analysis, have an understanding of curriculum development over time, be able to make learning tools, know the way to become successful teachers, and have good teaching skills. Thus the teacher will easier educate students confidently.

Tabel 3. Teacher Training and Development Materials Phase 3

\begin{tabular}{|c|c|c|}
\hline No. & Material & Session \\
\hline 1. & Service Excellent ॥ & 2 sessions \\
\hline 2. & Team Work II & 2 sessions \\
\hline 3. & Achievement Motivation Training (AMT) & 2 Sessions \\
\hline 4. & Teaching Tahsin Method (if there is a new one) & 1 session \\
\hline 5. & Latest Curriculum Surgery & 1 session \\
\hline 6. & Become an extraordinary teacher & 1 session \\
\hline 7. & Becoming entrepreneurship teacher & 1 session \\
\hline 8. & How to touch the heart & 1 session \\
\hline 9. & An easy way to teach the Qur'an & 2 sessions \\
\hline
\end{tabular}

Through interviews with principals and deputy principals of SDIT Iqra 1 City of Bengkulu, researchers found the intent of the follow-up material from the third stage of training and development material namely: this material wants to ensure teachers are able to portray themselves as professional teachers with high spirits, excellent service skills in work teams. Not only the material in table three equips the teacher in teaching the Qur'an and not just being an ordinary teacher.

Danim (2002) stated that teacher development and professional development career, including educational staff, are carried out through various strategies in the form of training (education and training) and training books, including: First, Education and training including the IHT (In-house training program) ) in the form of training carried out internally in teacher working groups, further education, namely the development of the teaching profession through further education, is also an alternative to improving teacher qualifications and competencies, internal coaching by schools, namely coaching conducted by the principal; Second, activities other than education and training include seminars. The seminar is an activity of fostering scientific publications that can also be a model of ongoing coaching for improving teacher professionalism. Then there are workshops, which are conducted to produce products that are useful for learning, competency enhancement, and career development. Making learning media, learning media that are made can be in the form of teaching aids, simple practical tools, as well as electronic teaching materials or learning animations.

The teachers of SDIT Iqra 1 Bengkulu are given training and development continuously and tiered. Teachers for three years of service are different from teachers who have more than three years of service. This was done in an effort to develop teacher's career. For career development the teachers are also given scholarship facilities and facilities to continue their higher education. This education and training will actually give birth to a sense of comfort accompanied by presenting teacher work commitments like this phrase: this training and education can indirectly improve the mental well-being and sense of security of education personnel, because they feel they have adequate knowledge and are able to carry it out (Pidarta, 2011:119).

Based on interviews and observations the researchers found that teachers who qualified for undergraduate education were given time and scholarships for college, as well as teachers with an undergraduate qualification for those who wanted to continue their school studies gave permission for time and educational financial assistance. With this opportunity, the quality of teachers and education can be improved. In order to improve the quality of SDIT IT Iqra Bengulu also holds a monthly meeting between the headmaster and all teachers, the core of the activity is studying the development of education and all teaching and learning processes in schools. In addition to this large meeting, a meeting was also held for all the teachers who taught in the lower classes (classes I, II, and III) and also the meetings of the upper class teachers (IV, V, and VI). This activity is useful to discuss more specifically the problems of teaching and learning during the two weeks, the problems faced can be discussed and addressed more quickly. Other activities include discussions regarding the latest educational developments that can be applied in schools. The affect employee perceptions during crises and after crises are determined by training and development, "their perceptions were influenced by the lack of access to 
training and development opportunities within their respective organizations" (Mitsakis, 2014:17).

The training materials and the development of religious understanding with ten competencies (muwashofat), namely: First, Salimul Aqeedah (aqidah straight). Creed is clean described in measurable indicators include namely: no associating with the genie, no asking for help rang refuge with the jinn, no telling by looking at the palm of the hand. Second, Shahihul worship (true worship) with indicators such as the: Ihsan in Thaharah, ihsan in a prayer, ihsan know by heart 's veins Adh Dhuha sd An Naas, payment zakat, fasting, intention for Hajj, commitment of the adab recitations, far from the great sin, fulfill the nadzar, expand greeting, limb of everything unclean, and others. Third, Matinul Khuluq (noble morals) with indicators including: no takabbur, not imma'ah (as long as they take part, have no principles), do not lie, do not berate, do not pit sheep, do not ghibah, do not make bad people as friends / friends, fulfill the promise, serve both parents (birrul walidain). Fourth, qadirun 'ala kasbi (independent) with indicators namely: stay away from sources of illicit income from usury away from gambling with all kinds of things avoid fraud acts of paying zakat does not delay in exercising the rights of others to save, although a little guarding public facilities, maintaining special facilities. Fifth, Mutsaqaful fikri (broad insight into his thinking) indicators, namely: both in reading and writing paying attention to the laws of recitation, studying marhalah makkiyah and mastering its characteristics to know 10 friends who are guaranteed to go to heaven knowing the law of thaharah knowing the law of prayer knowing the law of fasting. Sixth, Qawwiyyul jism (healthy and strong body) indicators are: clean body, clean clothes, clean shelter, commitment to exercise 2 hours every week, wake up before dawn, pay attention to healthy reading procedures, withdraw from smoking, commitment to eating and drinking according to the sunnah, not excessive in staying up late, avoiding dirty places of pollution avoiding places of disaster. Seventh, Mujhidun linafsihi (Serious) indicators, namely: stay away from everything that is unlawful, stay away from places of immorality away from places that are forbidden, and stay away from everything that is unclean. Eighth, Munadzhom fi syu'unihi (orderly and neat in each of his affairs) indicators, namely: do not establish relationships with institutions that oppose Islam, and do not establish relationships with institutions that oppose Islam. Ninth, arishun 'ala waqtihi (time discipline) indicators, namely: wake up early and spend time to study. Tenth, nafi'un lighairihi (useful for others) with its indicators namely: exercising the rights of both parents to help those in need to guide lost people to participate in joy, and marry an appropriate partner.

The training time and the development of religious competencies are held once a week with a group division system fostered by senior teachers and teachers determined by the school. All teachers must actively participate in all programs held by the school, for example as in the following table:

Tabel 4. Teacher Training and Development of Religious Competencies

\begin{tabular}{cll}
\hline No. & \multicolumn{1}{c}{ Activity } & Time \\
\hline 1. & Sunnah fasting Thursday and breaking the fast together & Thursday is the second week of the month \\
\hline 2. & $\begin{array}{l}\text { Tarhib Ramadhan: } \\
\text { a. } \quad \text { Tabligh Akbar } \\
\text { b. } \quad \text { Ramadan parade }\end{array}$ & 2 or 3 days before Ramadan fasting \\
\hline 3. & An evening of faith and taqwa (MABIT) for male teachers & \\
\hline 4. & Jihadah Ruhiyyah & 1 time per 2 months \\
\hline 5. & Sacrifice of sacrificial animals & f time per 2 months \\
\hline 6. & Inauguration of Islamic boarding school tahfidz al Qur'an & Tentative, at any time \\
\hline 7. & Murakaz al Qur'an & 3 days beginning of Ramadan \\
\hline 8 & Exchange gifts & 1 time every two months \\
\hline
\end{tabular}

Through interviews with principals and deputy principals of SDIT Iqra 1 Bengkulu, the researchers revealed the purpose of the training material and the development of teacher's religious competencies is to equip teachers conceptually and practically. Providing the teacher with spiritual worship, ceremonial Islam, getting used to sacrifice, giving, being familiar with the Qur'an is believed to make the teacher have the ability to balance between carrying out the duties of the teacher as his profession with the concept of religion. From the description above confirms that teachers with training management and development that are directed, measured, and with clear objectives will present teachers who have a sense of security, comfort, enthusiasm, optimism, creativity, solidity with their teams, and high-performance. Therefore SDIT Iqra 1 Bengkulu makes a training construction and balanced development to maintain the most important assets namely teachers. 
This is consistent with the phrase that: job demand and employee capacity must be balanced through orientation and training programs (development of educational competencies and religious knowledge competencies), both are urgently needed. This is consistent with the phrase: training and development is very important for the workforce to work more masterfully and better at work (Darodjat, 2015:2).

\section{CONCLUSION}

The selection of teachers at SDIT Iqra 1 Bengkulu is conducted based on grades and work commitments, so as to form teachers who are dedicated to quality and achievement. Teacher selection at SDIT Iqra 1 Bengkulu refers to the standards of integrated Islamic school teachers and work committees in the hope of getting quality teachers. The selection is done through two stages: First, a written test in the form of: a psychological test, a field of study test, a test of educational knowledge and the latest developments, after that the test participants are asked to gather the ability to make an integrated learning tool in the form. Second, the non-written test, namely: the teaching ability test that is micro teaching, the ability to read the Qur'an based on recitation, the memorization of the letters in the Qur'an, the ability to practice prayer, the prayer reading ability, and Prayer ability tests after Fard prayer. Interview, at the interview stage the teacher candidates are asked to commit not to test prospective civil servants (CPNS). Teachers who pass the test sign a memorandum of understanding (MoU) with the foundation. Teacher training and development conducted by SDIT Iqra 1 Bengkulu is in accordance with theoretical concepts. Training and development of SDIT Iqra 1 Bengkulu there are two focuses, namely the development of professional competence and religious competence, it is done in stages and as long as the teacher concerned teaches at SDIT IQRA 1 Bengkulu. With the development of these two competencies, professional and spiritual teachers are formed.

\section{REFERENCES}

Bangun, Wilson, (2012), Human Resources Management. Jakarta: Penerbit Erlangga.

Basri, Hasan dan Rusdiana, (2002), Training and Education Management. Bandung: Pustaka Setia.

Danim, Sudarwan, (2012), Educational profession. Bandung: Alfabeta.

Darodjat, Tubagus Achamd, (2015), Basic Concepts of Present Personnel Management, Bandung: Refika Aditama.

Halsey, A.H., Hugh Lauder, Phillip Brown, and Amy Stuart Well, (1997), Education: Cultre Economic Society. Oxford University Press.

Hasibuan, Malayu SP, (2011), Human Resources
Management, Jakarta: Earth Literacy.

Jackson, SE., RS. Schuler, and S. Werner, (2009), Human Resources Management, Jakarta: Salemba Empat.

Kartomo, Andhika P., (2016), Evaluation of Performance Certified Teacher. Journal of Management Education, Volume 3, No. 2

Kirsten, Petrie, and McGee, Clive, (2012), Professional Development Teacher: Who is the learner?. Australian Journal of Teacher Education: Vol. 3, 7: Iss. 2, Article 4.

Laws of Republik Indonesia Number 14 of 2005 Concerning Teachers and Lecturers Chapter IV Article 14 paragraph 1.

Laws of Republik Indonesia Number 20 of 2003, Concerning the National Education System. Article 1.

Mitsakis, Fotios V., (2014), Employees' perspectives on strategic human resource development before and after the global financial crisis: evidence from the Greek banking sector, "International Journal of Training and Development, doi: 10.1111/ ijtd.12112.

Moleong, L. J., (2007), Qualitative Research Methodology. Bandung: Youth Rosdakarya.

Muniroh, Jauharotul and Muhyadi, (2017), Education Management and Education Personnel in Madrasah Aliyah Negeri Yogyakarta City. Journal of Eduacation Management Accountability. Volume 5, Number 2, September 2017.

Noe, Raymond A. et al., (2010), Human Resource Management Achieving Competitive Advantage. Jakarta: Salemba Empat.

Palmer, Brandon, (2015), Principal Selection and School District Hiring Cultures: Fair or Foul?, California State University: Journal of Education \& Social Policy Vol. 2, Number 2.

Pidarta, Made, (2011), Indonesian Education Managemen. Jakarta: Rineka Cipta.

Prastowo, Andi, (2015), Changes in the Msetset and Readiness of Elementary School Teachers in Educational Competition in the Era of Mea, Proceedings of the National Seminar.

Presidential Instruction of the Republic of Indonesia Number 15 dated 13 September 1974.

Rohman, Miftahur, (2016), Problems of Teachers and Lecturers in the National Education System, Scholar Vol. 14 Number. 1.

Roschelle, et al., (2014), Recruiting Participants for Large-Scale Random Assignment Experiments in School Settings. Menlo Park, CA: SRI International.Rugayah, (2010), Educational Profession in the education perspective, Bandung: Alfabeta.

Rugayah, (2010), Education Profession in an Educational Perspevtive, Bandung: Alfabeta. 
Shabir, M. U, (2015), Position of teachers as educators: (Duties and Responsibilities, Rights and Obligations, and Teacher Competence), Auladuna, Volume. 2 Number. 2.

Sugiyono, (2017), R\&D, Qualitative, Quantitative Approach in Educational Research Methodology. Bandung: Alfabeta.

Tilaar, H.A.R, (2012), Standardization of National Education Review A an Critical, Jakarta: Rineka Copyright: 2012.

Widodo, Suparno Eko, (2017), Training Management, Jakarta: Jaya Media.

Yin, Robert K., (2008), Desin Case Study, and Method, Jakarta: Raja Grafindo Persada .

Yullyanti, Ellyta, (2009), Analisis Recruitment and Selection Process on Employee Performance, Business \& Bureaucracy, Journal of Administrative Sciences and Organizations, Volume 16, Number 3. 